\title{
Highly insulated pitched roofs resilient to air flow patterns: guidelines based on a literature review
}

\author{
Staf Roels*, Jelle Langmans
}

\author{
Department of Civil Engineering, Building Physics Section, KU Leuven, University of Leuven \\ Kasteelpark Arenberg 40 - bus 02447, BE-3001 Heverlee, Belgium \\ * Corresponding author. Tel: +32 16 321349; fax: + 3216321980 \\ E-mail address: staf.roels@kuleuven.be (S.Roels)
}

\begin{abstract}
This paper reviews previous research work on the effect of air movement on the heat transmission losses in light weight building components in general and pitched roofs in particular. Air movement in pitched roofs is typically a mixture of three phenomena: 1) in/exfiltration, 2) natural convection and 3) wind-washing. While the importance of air barrier systems to guarantee the thermal and hygric performance by the exclusion of exfiltration is widely acknowledged today, less emphasis is put on the necessity of a continuous wind barrier to prevent wind-washing of the insulation layer. Also the effects of small air leakages around the insulation layer which can trigger natural convection is currently underestimated in practice. Based on findings in the literature, guidelines are put forward on how to construct a pitched roof with a robust high thermal performance.
\end{abstract}

Keywords: pitched roofs; air flow; wind washing; natural convection; thermal performance

\section{Introduction and problem statement}

A sound thermal insulation is considered as a crucial step to reduce the energy use of new and existing buildings. As a result, most European member states tightened the U-value requirements for opaque building components to values below $0.25 \mathrm{~W} / \mathrm{m}^{2} \mathrm{~K}$. These requirements are typically evaluated in the design phase: the theoretical performance of the building component is calculated based on the thickness and thermal conductivity of the composing layers. It is however well-known that the actual achieved thermal resistance is not only a matter of the thickness of the insulation layer. Other than pure conduction phenomena, such as convective and latent heat transfer, can deteriorate the performance on site [1-3].

Looking at heat losses in pitched roofs in cold and moderate climates, air movement through the building component is considered as the malefactor, often resulting in a poor on-site performance 
compared to the design performance. Recently the British Board of Agrément, (BBA) one of UK's leading certification bodies, published a report on the air movement and thermal performance of pitched roof constructions [4]. The results and conclusions were based on experimental research in laboratory conditions making use of a modified Hot Box. By comparing the thermal resistance as a function of imposed air speed at the cold side of the roofs of three so-called 'standard build practice' roof configurations, a significant performance gap was observed for all roof types. On average across all three configurations, a 90\% increase was reported between calculated and measured U-value at wind speeds around $7.5 \mathrm{~m} / \mathrm{s}$.

Similar differences between calculated and measured U-value in laboratory conditions were reported by Deseyve and Bednar [5]. Most striking in both studies are not the obtained results as such similar results have been published in the 1990's [6] -, but the fact that the pitched roof constructions tested in these laboratory tests are considered as standard building practice. Deseyve and Bednar [5], for example, studied pitched roofs with low density glass wool $\left(14 \mathrm{~kg} / \mathrm{m}^{3}\right)$ with air layers around this insulation of $2 \mathrm{~cm}$. They claim this is according to the current building practice in Austria. Yet this was definitely not in agreement with design recommendations documented in previous research [6-8]. The same holds for the BBA-study [4] in which an underlay with two unsealed laps was used. Again, not corresponding to guidelines based on previous research [2].

The huge impact of air movement on the actual thermal performance of building enclosures has been studied extensively for decades. Already in 1989, Powell et al. [9] published a literature survey on the influence of air movement on the effective thermal resistance of porous insulations. Ever since, several studies investigated the effect of different air movement patterns on the thermal performance and durability of (mainly lightweight) building components [2, 6, 7, 8]. Several of those studies, resulted in guidelines and performance requirements of the composing material layers [10-12]. However, it seems that these (fragmented) recommendations did not lead to a roof construction resilient to air flow effects in day to day building practice, and this notwithstanding the rapid development in technology on improved air and wind barrier systems ${ }^{1}$. At the same time, recent research papers mainly focus either on detailed aspects of roof thermal performances, such as exterior surface finishing to avoid heat island effects [13-16], the impact of reflective underlay and air

\footnotetext{
${ }^{1}$ e.g. Tightvent newsletter which can be retrieved via www.tightvent.eu
} 
barriers [17-18], air flow in the vented cavity underneath the tiles [19-21] or on related aspects, such as integration of solar panels [22-25], wind loads [26-28] and (cold) attic performances [29-30], while a general overview combining research findings and recommendations to construct a pitched roof resilient to air flow seems to be lacking.

Therefore, the current article reviews previous research work on air movement in light weight building components in cold and moderate climates in general and pitched roofs in particular. In this study we focus on lightweight insulated sloped roofs, consisting of a wooden framing structure, insulated by filling the structural cavity in between the framing to avoid heat losses. A typical example of a such a pitched roof configuration is given in Figure 1. Herein the 'wind barrier' is positioned on top of the rafters to protect the insulation layer from unwanted infiltration of outside cold air by natural or forced convection. In addition, this exterior layer serves as drainage plane to prevent water infiltration into the structure. The air and vapour barrier functions are typically combined in one layer and provided at the inside of the building component.

Based on the literature, the first part of this paper reiterates the common air flow patterns and their effect on the heat transmission losses. In the second part, the observed findings are compiled in specific performance requirements and guidelines for good building practice for a pitched roof construction. When following these guidelines, the performance gap can be minimized and the actual thermal resistance of the roofs will be in line with the design values.

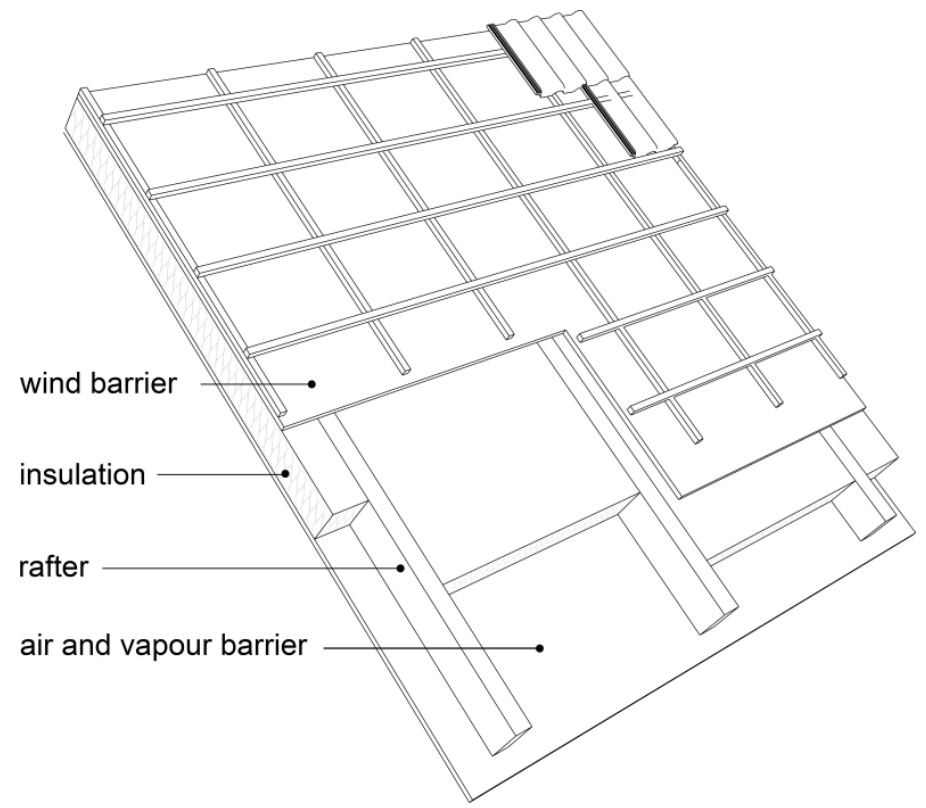

Figure 1: Schematic overview of a pitched roof with insulation installed in the cavity in between the structural framing. 


\section{Common air flow patterns and their effect on thermal performance}

The impact of air movement on the thermal performance of lightweight building components has been extensively studied in the literature. For pitched roofs, three different kinds of air flow patterns have to be accounted for: 1) air leakage (diffuse and concentrated), 2) natural convection and 3) wind washing. The first corresponds to forced convection due to deficiencies in - or even the lack of - an airtight layer. As a result, pressure differentials across the building envelope (be it induced by an indoor-outdoor temperature difference, by wind or by mechanical ventilation) will force the air to flow through the building component. For pitched roofs forced exfiltration conditions are most dominant, resulting not only in increased heat losses, but often also in moisture problems [2, 31]. The second pattern causes a reduced thermal performance of the building component due to free heat convection as a result of buoyancy driven air rotation in and around the insulation layer. Driving force is the temperature difference across the building component. The last air flow pattern, wind washing, results from the fact that commonly no stringent air tightness requirements are put forward for the exterior protective layer (the underlay). As a result, even with a good overall airtightness achieved, exterior air driven by wind pressure gradients may flow through air permeable insulation materials, again jeopardizing the designed thermal quality.

The reduction of the thermal performance of building components is often expressed by its Nusselt number $[2,32]$. This value is defined as the ratio of the components thermal resistance without $\left(R_{\text {cond }}\right.$ $\left.\left(\mathrm{m}^{2} / \mathrm{K} / \mathrm{W}\right)\right)$ and with $\left(\mathrm{R}_{\mathrm{cond}+\mathrm{conv}}\left(\mathrm{m}^{2} / \mathrm{K} / \mathrm{W}\right)\right)$ including air transport effects:

$$
N u=\frac{R_{\text {cond }}}{R_{\text {cond }+\operatorname{conv} v}}
$$

Figure 2 shows the different kind of air movements observed in sloped roofs: air leakage (diffuse and concentrated), natural convection in and around the insulation layer, and wind washing. Though these mechanisms typically occur as mixed processes, the next sections will try to quantify the impact of each of the different air flow patterns. Based on a literature review, the present article will conclude on the necessary requirements to avoid these air movements. 
a)

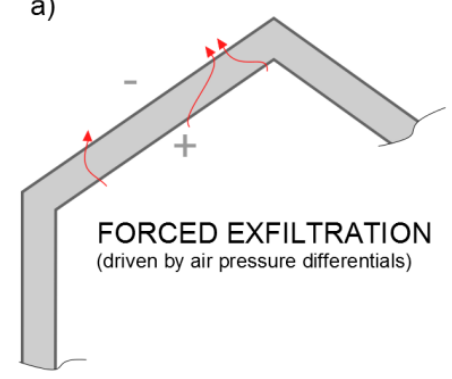

b)

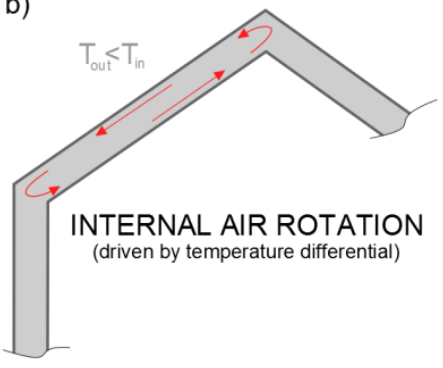

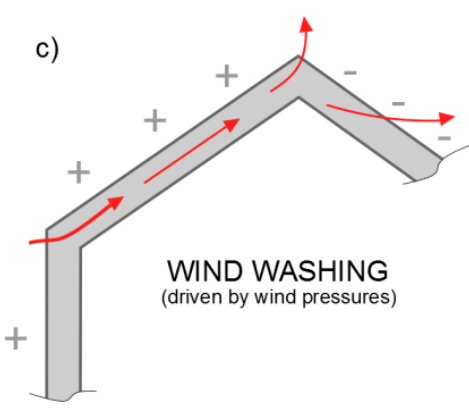

Figure 2: Possible air flow phenomena reducing the thermal performance of pitched roofs: a) forced exfiltration through the pitched roof, b) internal air rotation in and around the insulation layer and c) wind-washing of the insulating layer.

\subsection{Forced exfiltration}

Most straightforward form of air transport within sloped roofs is forced convection. This occurs when an air pressure differential is established across a building component including air leakages. The overall air pressure difference across the roof is induced by wind, temperature differences and/or mechanical ventilation. The distribution and order of magnitude of the leakage paths within the pitched roof determines the resulting air flow pattern. Desmarais et al. conducted a detailed laboratory investigation in which they distinguished between: a) long paths, b) concentrated paths and c) distributed (diffuse) leakage paths [33]. The shape of the air flow pattern highly influences the impact on the surfaced-averaged thermal performance of the building component. A concentrated air flow path will for example correspond to higher heat losses than a distributed air flow path with the same overall air leakage level.

In- and exfiltration in light weight building components can be readily avoided by installing a continuous airtight layer, commonly called the air barrier. Because in practise air barriers consist of different elements and joints, Straube and Burnett [11] propose to use the term air barrier system. Already in 1985, Di Lenardo et al. prescribed target values for the air permeability of air barrier systems, including anticipated joints and perforations. At that moment, an upper limit of 0.0094 $\mathrm{m}^{3} / \mathrm{m}^{2} / \mathrm{h} / \mathrm{Pa}^{2}$ was put forward for an air barrier system including joints [8]. This value was based on numerical simulations for the Canadian climate, considering both limit state values for moisture accumulation as well as an increase of the conductive heat transfer (up to 15\%) due to air leakages. This value has been tightened by Straube and Burnett, proposing an upper limit of $0.0047 \mathrm{~m} / \mathrm{m} 2 / \mathrm{h} / \mathrm{Pa}$ [11]. Apart from the requirements for the overall air tightness of the air barrier system, they stressed

\footnotetext{
${ }^{2}$ Linearized representation of the original data provided in [8]: $0.72 \mathrm{~m}^{3} / \mathrm{m}^{2} / \mathrm{h}$ at $75 \mathrm{~Pa}$
} 
the importance of other criteria, such as continuity, strength, durability and stiffness.

In addition to its-impact on the thermal performance of sloped roofs several researchers have addressed the importance of forced exfiltration on the moisture loads within these components [3436]. Due to its combined importance to avoid moisture problems and reduce energy losses by air exfiltration in pitched roofs the application of interior air barrier systems is well established in today's building practice.

\subsection{Internal air rotation}

Internal air rotation refers here to the temperature driven air flow patterns in a compartment with airtight boundaries. The magnitude of internal convection amplifies most significantly with increasing: (1) temperature difference $(\Delta T)$ across the element, (2) specific permeability $(k)$ and thermal conductivity $(\lambda)$ of the insulation layer and (3), the characteristic length which corresponds here to the thickness $D$ of the insulation layer. This is often represented by the Darcy-modified Rayleigh number $\left(R a_{D}\right)$ which correlates with the Nusselt number in porous insulation layers [32, 37]:

$$
R a_{D}=g \cdot \beta \cdot D \cdot \Delta T\left(\frac{\rho c}{v}\right) \frac{k}{\lambda}
$$

in which $D$ is the width of the layer, $\beta$ represents the thermal expansion coefficient of air $\left(3.710^{-3} 1 / \mathrm{K}\right)$, $v$ the kinematic viscosity of air $\left(1.410^{-5} \mathrm{~m}^{2} / \mathrm{s}\right), \mathrm{g}$ the gravity acceleration $\left(9.81 \mathrm{~m} / \mathrm{s}^{2}\right), \lambda$ the thermal conductivity $(\mathrm{W} / \mathrm{m} / \mathrm{K})$ of the layer and $\rho$ and $c$ the density $\left(\mathrm{kg} / \mathrm{m}^{3}\right)$ and the specific heat capacity $(\mathrm{J} / \mathrm{kg} / \mathrm{K})$ of the fluid respectively.

Most of the existing studies on natural convection in light weight building components are related to stud walls and insulated attic floors. These two building elements have a different thermal behaviour in terms of internal air rotations. For horizontal porous media, such as insulated attic floors, the air rotations only establish when a certain critical threshold is exceeded $\left(\operatorname{Ra}_{D}>39.6(-)\right)$. Above this point air rotation loops, so-called Bénard cells, can easily evolve with a fast growing impact on the thermal resistance of the elements (see Figure 3a). This topic of natural convection in attic floors is thoroughly studied and documented in Scandinavian countries [32,38-41].

Stud walls, on the other hand, do not have such a distinct threshold for the onset of natural convection and typically only one continuous air rotation loop will establish. Figure $3 a$ illustrates the correlation between $\mathrm{Nu}$ and $\mathrm{Ra}_{\mathrm{D}}$ for a vertical porous layer between airtight boundaries based on analytical and 
numerical modelling results from the literature [41-45]. Apart from an inclination angle, the composition of pitched roofs is basically very similar to stud walls; a porous insulation material protected by an inner and outer sheathing or foil material. Nield and Bejan show in [46] that sloped porous media with low $\mathrm{Ra}_{\mathrm{D}}$-numbers perform similar as vertical porous media in that a stable unicellular flow pattern will establish and that there is no distinct threshold for the onset of natural convection. The criterion for 'low Ra $a_{D}$-numbers' applied in [46] is (see Figure $3 b$ ):

$$
R a_{D} \leq \frac{4 \pi^{2}}{\cos (\alpha)}
$$

For $\mathrm{Ra}_{\mathrm{D}}$-numbers exceeding this value multiple cells will develop in the form of polyhedral cells for small inclinations and longitudinal helicoidal cells for larger values (see figure $3 b$ ). For these levels of $R a_{D}$-numbers the heat transfer may depend on the slope of the porous medium with an existence of a maximum heat transfer rate at $\alpha=45^{\circ}$ to $60^{\circ}$ for $\operatorname{Ra}_{D} \leq 350$.
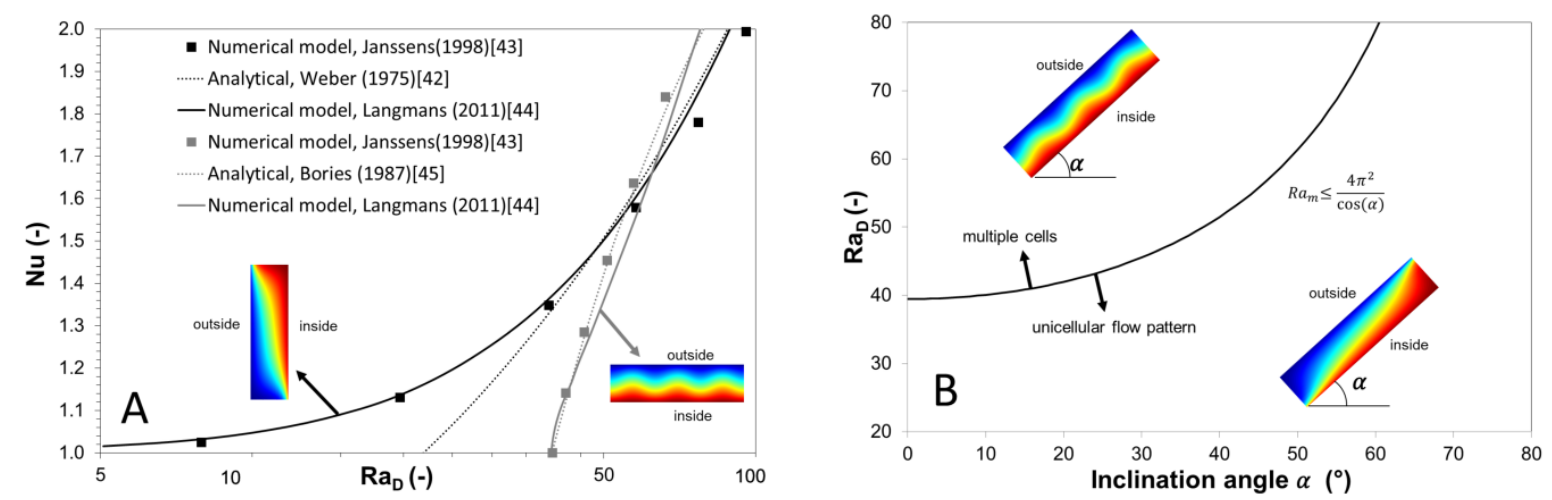

Figure 3: a) Relation between $\mathrm{Nu}$ and $\mathrm{R} \mathrm{a}_{\mathrm{D}}$ for vertical and horizontal porous media with airtight boundaries (based on results from [42-45]) and b) transition between unicellular and multicellular air flow patterns for inclined porous media as a function of $R a_{D}$ and the inclination angle (figure based on46]).

Figure 3 illustrates the correlation between $\mathrm{Nu}$ and $\mathrm{Ra} \mathrm{D}_{\mathrm{D}}$ for a wide range of configurations. To put these graphs in perspective, Table 1 provides an overview of the $R a_{D}$ corresponding to typical pitched roof configurations and materials. Table 1 takes two different insulation materials (glass wool vs. cellulose), two temperature differences $\Delta \mathrm{T}\left(20^{\circ} \mathrm{C}\right.$ vs. $\left.40^{\circ} \mathrm{C}\right)$ and two insulation thicknesses $(15 \mathrm{~cm}$ vs. $25 \mathrm{~cm}$ ) into consideration for a pitched roof with a slope of $45^{\circ}$. The $R a_{D}$ numbers in Table 1 are calculated according to Eqn. 2. Herein, the specific permeabilities of the insulation materials are adopted from [47]. 


\begin{tabular}{|c|c|c|c|c|c|c|c|c|}
\hline \multirow{3}{*}{$\begin{array}{c}\text { inclination angle }=45^{\circ} \\
\text { density }\left(\mathrm{kg} / \mathrm{m}^{3}\right)\end{array}$} & \multicolumn{4}{|c|}{ FIBREGLASS INSULATION } & \multicolumn{4}{|c|}{ CELLULOSE INSULATION } \\
\hline & \multicolumn{2}{|c|}{$D=15 \mathrm{~cm}$} & \multicolumn{2}{|c|}{$D=25 \mathrm{~cm}$} & \multicolumn{2}{|c|}{$D=15 \mathrm{~cm}$} & \multicolumn{2}{|c|}{$D=25 \mathrm{~cm}$} \\
\hline & $\Delta T=20^{\circ}$ & $T=40^{\circ}$ & $\Delta T=20^{\circ}$ & $\Delta T=40^{\circ}$ & $\Delta T=20^{\circ}$ & $\Delta T=40^{\circ}$ & $\Delta T=20^{\circ}$ & $\Delta T=40^{\circ}$ \\
\hline 10 & $9.1-29.4$ & $18.3-58.7$ & $15.2-48.9$ & $30.5-97.8$ & & & & \\
\hline 15 & $2.2-3.9$ & $4.3-7.7$ & $3.6-6.4$ & $7.2-12.8$ & & & & \\
\hline 20 & $0.8-0.9$ & $1.5-1.8$ & $1.3-1.5$ & $2.6-3.0$ & & & & \\
\hline 25 & $0.3-0.3$ & $0.7-0.6$ & $0.6-0.5$ & $1.2-1.0$ & & & & \\
\hline 30 & $0.1-0.2$ & $0.2-0.4$ & $0.2-0.3$ & $0.4-0.6$ & & & & \\
\hline 35 & & & & & $0.35-0.56$ & $0.70-1.12$ & $0.59-0.93$ & $1.17-1.87$ \\
\hline 40 & & & & & $0.23-0.34$ & $0.46-0.68$ & $0.38-0.56$ & $0.76-1.13$ \\
\hline 45 & & & & & $0.16-0.22$ & $0.31-0.43$ & $0.26-0.36$ & $0.52-0.72$ \\
\hline 50 & & & & & $0.11-0.16$ & $0.22-0.31$ & $0.18-0.26$ & $0.37-0.52$ \\
\hline 55 & & & & & $0.11-0.11$ & $0.21-0.23$ & $0.18-0.19$ & $0.35-0.38$ \\
\hline
\end{tabular}

Table 1: RaD as a function of the insulation (material, density), temperature difference $\Delta T$ and the insulation thickness for a roof with inclination angle of $45^{\circ}$ (minimum-maximum).

Table 1 illustrates that only for very low density insulation materials $\left(<10 \mathrm{~kg} / \mathrm{m}^{3}\right)$ multiple cells may occur in pitched roofs. For insulation densities from $15 \mathrm{~kg} / \mathrm{m}^{3}$ onwards the $\mathrm{Ra}_{\mathrm{D}}$ are far beyond the threshold value from which multiple cells develop. As a consequence research results regarding internal air rotations in stud walls are also applicable for pitched roofs with insulation materials with these density levels.

The first studies investigating the effects of air movement on the thermal performance of vertical permeable insulation systems occurred in the late fifties [48]. These experimental studies demonstrated that low density insulations $\left(<10 \mathrm{~kg} / \mathrm{m}^{3}\right)$ may lead to convection loops in and around the insulation layer, significantly increasing the overall heat losses through these elements. Hereafter many authors have examined the same effect for various configurations and temperature differences across the components in laboratory conditions [49-53]. A first comprehensive literature review on this topic has been written by Powell et al. [9]. Their review mainly distinguishes between two configurations, studied at that time: (1) a cavity filled with an open porous insulation material and (2) an air cavity partly filled with a thermal insulation layer. Powell et al. [9] discuss three air flow patterns which may occur in these configurations. Figure 4a-c transform these three types of convection scenarios to a pitched roof configuration. Pattern $\mathrm{A}$ in this figure corresponds to free convection inside the insulation layer. Pattern B refers to convection that bypasses the insulation layer through small gaps around this layer, and finally pattern $\mathrm{C}$ shows a convection loop pattern in partially filled cavities. In addition to these three unicellular air flow patterns described in [54] multiple cells may develop in 
pitched roofs which is illustrated in pattern D. Surely, combinations of these four air flow patterns likewise occur.

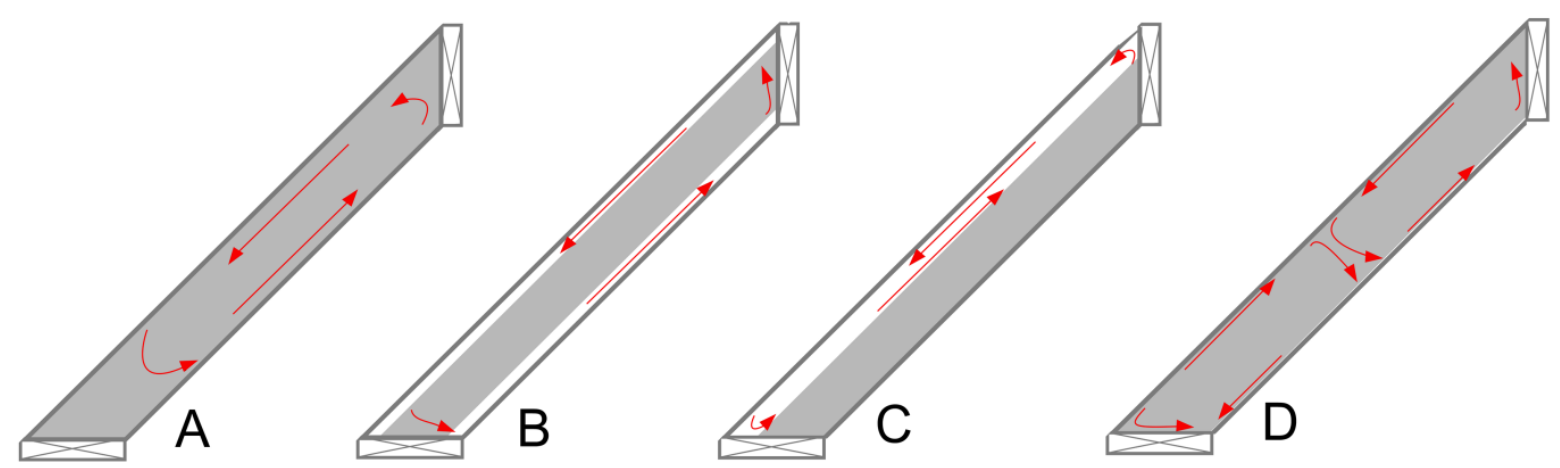

Figure 4: Types of internal air flow paths in pitched roofs: A) air rotation within insulation layer, B) air flow within gaps/channels around the insulation layer, $C$ ) air rotations in partly filled cavities and $D$ ) multicellular flow pattern.

In summary, the studies under review in [9], generally conclude that the impact of natural convection on the thermal performance is limited when at least one of the adjacent layers is airtight, air gaps along the interface ${ }^{3}$ between the sheathing and insulation are avoided and sufficiently dense insulation materials $\left(>20-30 \mathrm{~kg} / \mathrm{m}^{3}\right)$ are applied.

According to ISO:10456(2007) [55] the effect of natural convection on the thermal resistance of walls can be neglected for values of $\mathrm{Ra}_{\mathrm{D}}$ below 2.5 [12].

For pitched roofs an inclination factor should be introduced in Eqn. 2 by multiplying with the sinus of the inclination angle $(\alpha)$. The maximum Rayleigh number $\left(\mathrm{Ra}_{\mathrm{D}, \mathrm{max}}\right)$ proposed in [55] can be translated to a recommendation regarding the ratio between the specific permeability of the insulation layer and its thermal conductivity $\left(\frac{\mathrm{k}}{\lambda}\right)$. For a typical pitched roof element with a thickness of $20 \mathrm{~cm}$ and an inclination angle of $45^{\circ}$, this ratio corresponds to $1.810^{-8} \mathrm{mK} / \mathrm{W}$. For typical insulation materials with a thermal conductivity between $0.035-0.04 \mathrm{~W} / \mathrm{m} / \mathrm{K}$ this results in a maximum specific permeability level of 7-8 $10^{-9} \mathrm{~m}^{2}$. This can be achieved with standard glass wool blankets of $20-30 \mathrm{~kg} / \mathrm{m}^{3}$ which have a specific permeability of $3.2-5.310^{-9} \mathrm{~m}^{2}$ [35].

Note that the provided correlations between $\mathrm{Nu}$ and $\mathrm{Ra}_{\mathrm{D}}$ given so far relate to perfectly installed insulation layers. Many of the above-mentioned experimental studies however mention the

\footnotetext{
${ }^{3}$ At that time it was common building practise to provide an air layer between the underlay and the insulation material to promote drying of the structure. This was discouraged by later studies as this air layer most often appeared to have negative impact on the hygrothermal performance [30-31]
} 
susceptibility of these systems to bad workmanship. Next paragraph zooms in on literature results, quantifying the effect of typical installation errors. Three typical installation defects are documented in the literature: (1) air leakages around the corners of insulation blankets, (2) a vertical air path between the interface of insulation blankets and sheathing material, and (3) a horizontal air cavity at the top of loose fill insulation. The first defect typically occurs when installing insulation blankets, which are cut slightly oversized, so they can be squeezed in the stud cavity. As a result, typical imperfections are located at the corners of the insulation layer. An extensive study on the influence of these minor installation defects on the surface-averaged thermal resistance has been performed in Canada on full-scale test walls in laboratory conditions [7]. They investigated three insulation densities ranging from 9 to $35 \mathrm{~kg} / \mathrm{m}^{3}$ and three types of defects. Though the air leakages were only concentrated in the corners of the cavity, their study indicated an increased presence of natural convection over the entire width of the component. In [7] it is concluded that even for the highest insulation densities tested $\left(35 \mathrm{~kg} / \mathrm{m}^{3}\right)$, the thermal surface-averaged resistance was decreased with $2 \%$ as a result of these minor defects $\left(\Delta T=25^{\circ} \mathrm{C}\right)$. For lower insulation densities $\left(14 \mathrm{~kg} / \mathrm{m}^{3}\right)$ and higher temperature differences across the element $\left(55^{\circ} \mathrm{C}\right)$ the reduction reached up to $40 \%$.

A second type of imperfection occurs when the insulation blanket is not in tight contact with the adjacent surfaces. The effect of such (very) small cavities on the thermal behaviour has been studied in Norway [56-58]. They conducted comprehensive laboratory investigations combined with numerical simulations to study the effect of natural convection in highly insulated timber frame walls. A first series of simulations, presuming tight contact between the insulation and adjacent surfaces, systematically underestimated the measured heat transport. Yet, additional numerical simulations including small vertical leakages at these interfaces showed better agreement with the measurements. The simulations in [58] indicated that gaps of $3 \mathrm{~mm}$ on both sides of the insulation layer decreased the overall thermal resistance with $3 \%\left(\right.$ at $\left.\Delta T=20^{\circ} \mathrm{C}\right)$. This reduction becomes far more pronounced when the vertical channels are accompanied with (small) horizontal paths at the top and bottom of the wall, resulting in a convection loop bypassing the insulation layer. To overcome this reduced thermal performance of highly insulated walls in Norwegian Passivhaus construction, Uvsløkk et al. recommends to divide the insulation in two layers by providing a vertical convection barrier [12]. In addition, it is stated in [12] that the threshold $R a_{D}$-value of 2.5 , proposed by ISO:10456(2007) [55], is insufficient in that typical installation defects are not considered. 
A third kind of imperfection corresponds to settling of loose fill insulation leaving a horizontal gap at the top of the stud cavity. The impact of such defects on free heat convection has been studied by Riesner on full-scale test walls for cellulose and expanded polystyrene loose fill insulation [59]. The test walls studied had a total height of $2 \mathrm{~m}$ of which the upper $6 \mathrm{~cm}$ was left un-insulated providing an air gap over the entire depth of the wall. This study showed the development of a second convection loop inside the upper air gap. Consequently, this convection loop in the upper air gap counterattacked the main convection loop within the insulation layer. Based on the measured temperature profiles in the middle of the insulation layer, Riesner [59] demonstrated that the heat transport in the insulation was only influenced in the upper $25 \mathrm{~cm}$. The overall heat transfer of this configuration increased with $13 \%$ as a result of the settled insulation. It should be emphasised, however, that this reduced thermal performance was the result of local effects at the top of the wall. This is in contrast to the first two installation defects in which the main convection loop in the insulation was amplified.

\subsection{Wind washing}

The previous section restricted the discussion to internal air rotations effects, presuming an ideal situation in that the insulation layer is enclosed between two airtight layers. Nevertheless, in reality the exterior protective layer (wind barrier) is most often not sufficiently airtight. As a consequence exterior air may flow through permeable insulation materials driven by pressure gradients on the building envelope. First laboratory investigations on the thermal impact of wind-washing have been documented in $[55,56]$. Timusk et al. performed experiments on full-scale corners of wood frame walls exposed to wind conditions. They illustrated that defects in the wall sheathing may result in a cooling of the wall surfaces as a result of air flow [60]. Later, Uvsløkk conducted full-scale laboratory measurements on wind-washing effects in timber frame walls [6]. The applied exterior pressure difference, based on in situ measurements, was realized by imposing a pressure difference at the walls cladding in- and outlet. Based on these measurements, Uvsløkk proposed in [6] a maximum overall air permeability of the wind barrier system of $0.05 \mathrm{~m}^{3} / \mathrm{m}^{2} / \mathrm{h} / \mathrm{Pa}$. Ojanen \& Kohonen [61], at their turn, found similar threshold values by numerical simulation. These additional simulation results illustrated that compartmentation of the insulation layer reduced wind-washing. As a consequence, Ojanen \& Kohonen [61] suggested a maximum air permeance of $0.036 \mathrm{~m}^{3} / \mathrm{m}^{2} / \mathrm{h} / \mathrm{Pa}$ when strong corner convection is possible and $0.09 \mathrm{~m}^{3} / \mathrm{m}^{2} / \mathrm{h} / \mathrm{Pa}$ when the building envelope is divided in separate 
structures. Later also Deseyve and Bednar [5] studied the effect of wind-washing in laboratory conditions. They tested pitched roofs with low density glass wool blankets $\left(14 \mathrm{~kg} / \mathrm{m}^{3}\right)$ and air channels along the insulation layer $(2 \mathrm{~cm})$. They report a significant increase of local heat fluxes $(300 \%-900 \%)$ in these elements as a function the imposed air pressure differential between (unsealed) eave and ridge. However, their study did not propose recommendations to avoid these air flows.

In addition to these laboratory measurements, Janssens \& Hens [2] studied wind washing effects on in situ vented and compact pitched roofs in Belgium. They examined the overall air flow patterns with tracer gas tests and temperature and heat flux sensors installed at three heights. Figure 5 shows the impact of sealing the joints in the wind barrier on the thermal performance of the compact pitched roofs. The authors state that the air barrier function of the roof is guaranteed by the inner gypsum board layer. First, the roof was tested with the overlaps in the wind barrier foil left unsealed, corresponding to common building practice. Therefore, the same roof element was tested with the joints in the wind barrier sealed. The results indicate that pitched roofs without a sealed wind barrier may reach Nusselt numbers up to 1.5-2 (-) at wind speeds of $5 \mathrm{~m} / \mathrm{s}$ at the windward side for a pitched roof with a completely filled insulation compartment (compact roof). When the wind barrier was sealed the Nusselt numbers fall below 1.2 at the level of the ridge (see Figure 5). However, this effect was far less pronounced in the middle of the roofs and near the eaves. The authors justify this by the large air permeance of the underlay material compared to the upper limits recommended in literature.

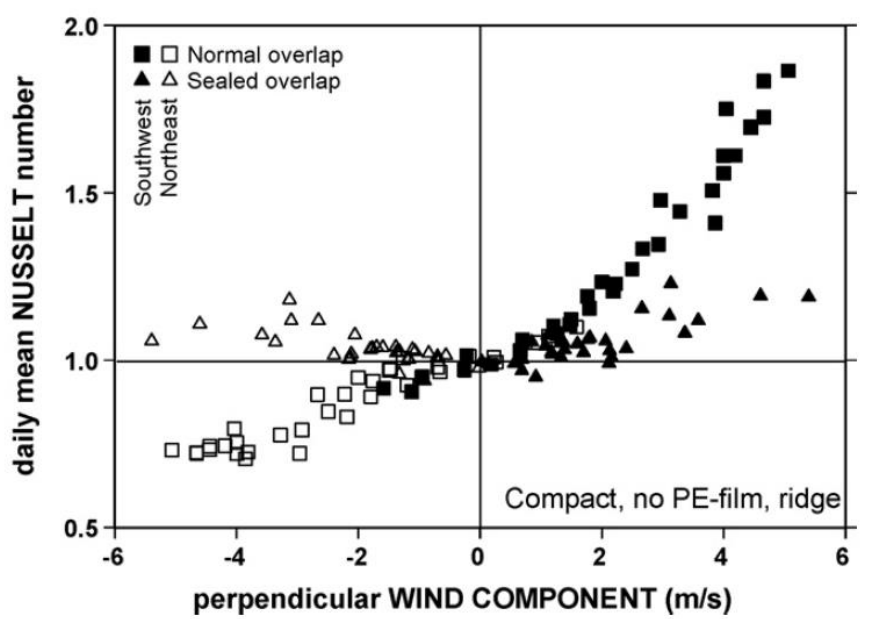

Figure 5: Impact of the thermal performance of pitched compact roof at one meter from the ridge as a function of the wind speed: impact of sealing the joint overlap on the daily mean Nusselt number [2].

In summary, the measured reduction of the surface averaged thermal resistance of roofs for a wind of $4 \mathrm{~m} / \mathrm{s}$ coming from a direction perpendicular to the roof was $10 \%$ for entirely insulated elements 
(compact roofs) and $40 \%$ for partly insulated roof elements (vented roofs). Based on these in situ measurements, the authors recommended to seal the wind barrier layer in duo-pitched roofs to improve their air permeance levels to the proposed values of [6] and [61]. These postulated recommendations notwithstanding, the vast majority of the current building practice still not seals the wind barrier to prevent wind-washing.

\section{A robust pitched roof is possible}

The literature review in the previous section revealed that the thermal performance of pitched roofs may be significantly affected by air flow patterns. At the same time, based on their findings, several researchers put forward guidelines and performance targets to make the roofs less vulnerable to air flow effects. This section compiles for each of the air flow patterns all outcomes to come up with general guidelines on how to construct a pitched roof with a robust thermal performance.

First of all, to avoid air leakage, the construction should contain a continuous airtight layer, the socalled air barrier system. This air barrier system has to preclude in- and exfiltration through the roof component. As upper limit a maximum air permeability of $0.0047 \mathrm{~m}^{3} / \mathrm{m}^{2} / \mathrm{h} / \mathrm{Pa}$ can be maintained. Note however, that in addition to the airtightness of the material layer (which can easily be measured and achieved [62]), the continuity of the air barrier system is far more important to guarantee a good airtightness of the overall system. Therefore, a typical interior finishing as for instance coated gypsum board (that easily fulfils the air permeability requirements) is often not considered sufficient since achieving continuity is hard at service penetrations, wall-roof interfaces, etc.. Furthermore, cracks in the inner lining might appear due to wind gust loads on the roof. That is why common guidelines [36] propose to separate the interior lining and air barrier system, and to install them at different positions to avoid damage of the air barrier system when perforating the lining. In European countries often an air-vapour barrier system is used at the warm side of the insulation to avoid both air leakage through the component, as well as vapour diffusion and convection. Alternatively, a warm roof construction (similar to a flat roof design) could be applied, in which the location of the air (vapour) barrier system, insulation and outside finishing is placed on top of the structural sheathing and framing [63-64]. 
Once forced exfiltration is excluded by a sound air barrier system, it is important to avoid air rotation by natural convection within the roof component. It has been shown in section 2.2 that the thermal resistance of insulation layers can be significantly degraded by natural convection. Convection loops were found to be highly triggered by air cavities or even small air gaps between insulation layer and boundary surface $[7,58]$. Therefore, a tight contact between insulation and both interior and exterior surface will be important to reduce the risk on air rotation. This asks for a compact roof. But even when air gaps along underlay and interior air barrier system are avoided, internal air loops through low-density fibrous insulation layers may occur [9]. To reduce the impact of natural convection, several studies $[12,65]$ propose the application of denser insulation materials $\left(>20 \mathrm{~kg} / \mathrm{m}^{3}\right)$. Also blown in insulation was found to be more resilient to air looping than insulation blankets. Not only is the risk on small air gaps lower when insulation is blown into the compartment, often also higher insulation densities are applied.

Last, but not least, and unfortunately often overlooked, wind-washing should be avoided. Even with an interior air barrier system fulfilling passive house standard ${ }^{4}$, cold outside air might penetrate in the insulation layer due to wind induced forced convection and leave the construction again at another position, but now as warm air. Pitched roofs are rather susceptible to wind-washing as wind will induce steep pressure gradients along the roof sides. To avoid this, an additional airtight layer is foreseen at the outside, the so-called wind barrier. Following Uvsløkk [6] and Ojanen \& Kohonen [61] an upper limit of $0.036-0.05 \mathrm{~m}^{3} / \mathrm{m}^{2} / \mathrm{h} / \mathrm{Pa}$ is put forward for the air permeability of the wind barrier. Most roof underlay materials fulfil these requirements and can take up the role of wind barrier. In addition to the air permeance requirements of the underlay, the field study of Janssens \& Hens [2] stressed the importance of a continuous wind barrier. This is important, as for its original function of drainage plane, no sealed joints are requested, but an overlap is sufficed. The continuity of air tightness of the underlay often results in adapted building details. Whereas a continuous wind barrier is feasible in the roof surface itself, it is harder to achieve at eave and ridge joints. An example of a possible eave and ridge detail is shown in Figure 6. In the eave detail a pre-installed airtight strip is used to make a continuous air tight connection between wind barrier and interior air barrier system, securing the insulation layer for wind-washing.

\footnotetext{
${ }^{4}$ Passive house standard explicitly require an overall building airtightness of $n_{50}=0.61 / h$
} 

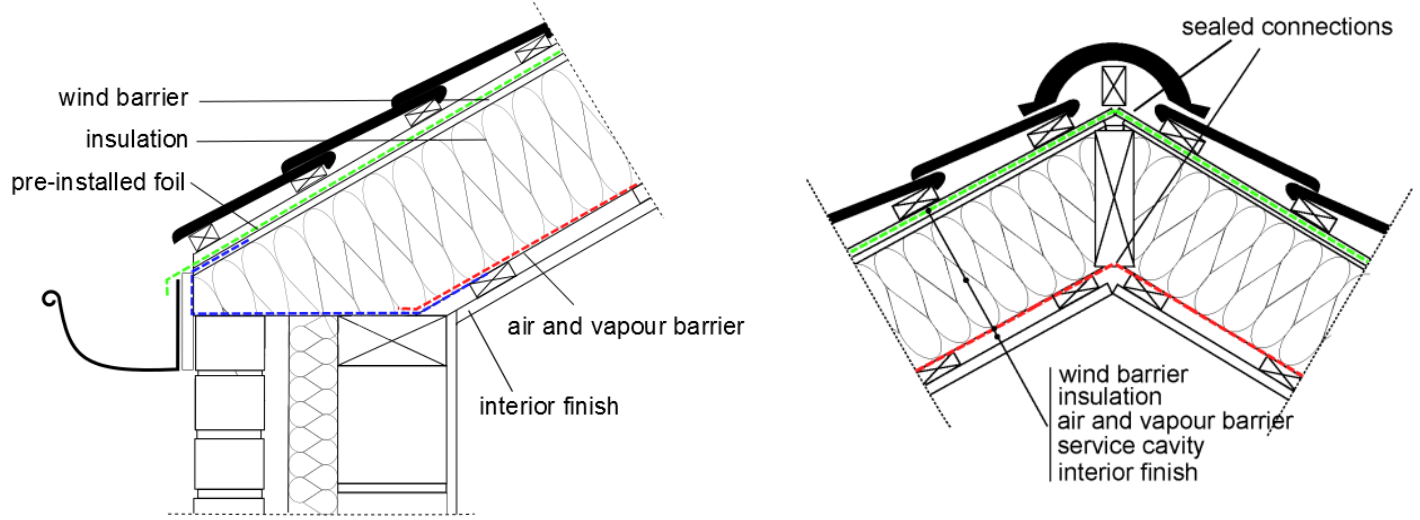

Figure 6: Example details for pitched roofs to avoid air exfiltration and wind-washing: a) connection of the interior air barrier with the exterior air barrier to obtain a continuous protection at the level of the eaves and b) sealing of the wind and air barrier at the ridge.

A summary of the obtained guidelines for pitched roofs based on the different studies is presented in Table 2. This table again distinguishes between the three main air flow patterns in pitched roofs. First, Table 2 provides threshold values for the air barrier system. It is important to note these values refer to the air barrier system and not to the averaged airtightness in a building project. Di Lenardo [66] outlines a method to determine the air barrier systems air leakage based on a $2.4 \mathrm{~m}$ by $2.4 \mathrm{~m}$ test samples including typical connections. Herein the specimens are constructed according to the installation instructions provided by the system proponent to represent the field situation since the way a system is constructed is often the most decisive parameter in air barrier system performance [67].

Next, to avoid natural convection, upper limits regarding the air permeability of the insulation are provided in the literature. Yarbrough and Wudhapitak [47] shows a good correlation between the insulation density and its air permeability. As most often insulation manufacturers do not provide air permeability information Table 2 provides upper limits regarding the insulation density. While the results of Brown [7] show that a density of $13 \mathrm{~kg} / \mathrm{m}^{3}$ is sufficient to avoid significant rotation loops, the field measurements on pitched roofs in [54], in which glass wool of $14 \mathrm{~kg} / \mathrm{m}^{3}$ is used, clearly illustrate that these densities are still susceptible for a reduction of the thermal performance due to natural convection. It is therefore advised to apply densities of $20 \mathrm{~kg} / \mathrm{m}^{3}$ or higher as stated in [9] and [12]. Further, it is also recommended by several scholars to fill the insulation compartment completely (socalled compact roof) and to avoid small air channels (1-2 $\mathrm{mm}$ ) around the insulation layer.

Finally Table 2 concludes on upper air permeability level which the exterior wind barrier should meet. This is approximately an order of magnitude higher than the common air barrier systems requirement. 


\begin{tabular}{ccc}
\hline Component & Requirement & Reference \\
& Air barrier material & \\
& $<0.00096 \mathrm{~m}^{3} / \mathrm{m}^{2} / \mathrm{h} / \mathrm{Pa}$ & \\
Air barrier system & $<0.0018 \mathrm{~m}^{3} / \mathrm{m}^{2} / \mathrm{h} / \mathrm{Pa}$ & {$[8-10]$} \\
& Air barrier system & {$[62]$} \\
& $<0.0047 \mathrm{~m}^{3} / \mathrm{m}^{2} / \mathrm{h} / \mathrm{Pa}$ & \\
& $<0.0096 \mathrm{~m}^{3} / \mathrm{m}^{2} / \mathrm{h} / \mathrm{Pa}$ & {$[11]$} \\
& density & {$[8-10]$} \\
\hline Insulation layer & $>13 \mathrm{~kg} / \mathrm{m}^{3}$ & {$[7]$} \\
& $>21 \mathrm{~kg} / \mathrm{m}^{3}$ & {$[9]$} \\
& $20-30 \mathrm{~kg} / \mathrm{m}^{3}$ & {$[12]$} \\
& Application & {$[68]$} \\
& Filled insulation compartment & {$[7,58]$} \\
Avoid small air channels & {$[6]$} \\
& Air permeability & {$[61]$} \\
& $<0.05 \mathrm{~m}^{3} / \mathrm{m}^{2} / \mathrm{h} / \mathrm{Pa}$ & \\
& $<0.036-0.09 \mathrm{~m}^{3} / \mathrm{m}^{2} / \mathrm{h} / \mathrm{Pa}$ &
\end{tabular}

\section{Discussion \& conclusions}

Contrary to some recent conclusions [4-5] in which a significant performance gap (up to $90 \%$ of the surface-averaged thermal resistance in [4]) was observed for pitched roof assemblies, the previous section illustrated that it is possible to construct a well-performing and robust pitched roof with high thermal quality and resilient to air flow patterns. To do so, the following advices should be taken into account:

- To avoid wind washing and air looping, create a compact roof, i.e. fill the cavity between the underlay and the air and vapour barrier over the total height of the rafters and use an insulation material with a high enough density $\left(>20 \mathrm{~kg} / \mathrm{m}^{3}\right)$ and some compressibility.

- Apply a continuous air (and vapour) barrier system at the inside of the insulation layer, in order to assure the air tightness of the roof construction when the internal lining is perforated. The overall air permeability of the air barrier system should be lower than $0.0047 \mathrm{~m}^{3} / \mathrm{m}^{2} / \mathrm{h} / \mathrm{Pa}$. Furthermore, make sure that the internal lining and air barrier are at different positions, so that the lining can be perforated without damaging the air barrier.

- Apply a sufficiently airtight underlay (air permeance $<0.036-0.05 \mathrm{~m}^{3} / \mathrm{m}^{2} / \mathrm{h} / \mathrm{Pa}$ with sealed joints (or airtight tongue and groove system). Pay attention to an airtight detailing of the eaves and the ridge (see for example on Figure 6). 
- To increase the thermal quality even more, the cavity between air and vapour barrier and interior lining can be insulated. Air flow has hardly any impact on the thermal performance of this cavity and the extra insulation layer gives additional support to the air barrier system, increasing its lifetime and durability.

\section{References}

[1] Hens, H., Janssens, A., Depraetere, W., Carmeliet, J., Lecompte, J. (2007). Brick Cavity Walls: a Performance Analysis Based on Measurements and Simulations,. Journal of Building Physics, 31 (2), 95-124.

[2] Janssens, A. \& Hens, H. (2007), 'Effects of wind on the transmission heat loss in duopitched insulated roofs: A field study', Energy and Buildings 39(9), 1047-1054.

[3] Lowe, RJ., Wingfield, J., Bell, M., Bell, JM. (2007). Evidence for significant heat losses through party wall cavities in load-bearing masonry construction. Building Services Engineering Research and Technology 28(2), 161-181.

[4] BBA (2012) Air movement and thermal performance - An investigation into the effect of air movement on the thermal performance of domestic pitched roof constructions. British Board of Agrément, Technical Report nr. 1.

[5] Deseyve C. and Bednar T. (2008) Wind induced airflow through lightweight pitched roof constructions: Test roof element - measurements and model validation, Copenhagen, $8^{\text {th }}$ Nordic symposium on building physics

[6] Uvsløkk, S. (1996), 'The Importance of Wind Barriers for Insulated Timber Frame Constructions', Journal of Thermal Insulation and Building Envelopes, 20(1), 40-62.

[7] Brown, W. C., Bomberg, M. T., Ullett, J. M. \& Rasmussen, J. (1993), 'Measured thermal resistance of frame walls with defects in the installation of mineral fibre insulation', Journal of Thermal Insulation and Building Envelopes 16(4), 318-339.

[8] Di Lenardo, B., Brown, W. C., Dalgliesh, A., Kumaran, K. \& Poirier, G. (1995), Technical guide for air barrier systems for exterior walls of low-rise buildings, Technical report, Candian Construction Materials Centre, NRC, Ottawa, Ontario.

[9] Powell, F., Krarti, M. \& Tuluca, A. (1989), 'Air movement influence on the effective thermal resistance of porous insulations: a literature survey', Journal of Thermal Insulation and Building Envelopes 12(3), 239-251.

[10] National Building Code of Canada 1995, Institute for Research in Construction, National Research

Council Canada, Appendix A-9.25.1.2.

[11] Straube, J. 2011. High Performance Building Enclosures. Somerville, MA: Building Science Press [12] Uvsløkk, S., Skogstad, H. B. \& Grynning, S. (2010), How to prevent natural convection causing extra heat loss and moisture problems in thick insulation layers, in '3rd Nordic Passive House Conference 2010 -Towards 2020 Sustainable Cities and Buildings'.

[13] Marino, C., Minichiello, F. \& Bahnfleth, W. (2015). The influence of surface finishes on the energy demand of HVAC systems for existing buildings. Energy and Buildings, 95 (SI), 70-79.

[14] Asadi, S., Hassan, M., Beheshti, A. et al. (2015). Quantification of residential energy consumption reduction using glass-modified asphalt shingle. Journal of Architectural Engineering, 21(4).

[15] Kiletico, M. Hassen, M. Mohammad, L. et al. (2015). New approach to recycle glass cullet in asphalt shingles to alleviate thermal loads ad reduce heat island effects. Journal of Materials in Civil Engineering, 27(8).

[16] Rosado, P. Faulkner, D., Sullivan, D. et al. (2014). Measured temperature reductions and energy savings from a cool tile roof on a central California home. Energy and Buildings, 80, 57-71.

[17] Enache, I., Braga, D., Portet, C. et al. (2009). Evaluation of insulation systems by in situ testing, in '14th International Conference on Computational Methods and Experimental Measuremetns', Ed. Brebbia, CA. \& Carlosmagno, GM. WIT Transaction on modelling and simulation, Vol. 48, 147-156. [18] Roels, S. \& Deurinck, M. (2011). The effect of a reflective underlay on the global thermal behavior of pitched roofs. Building and Environment, 46, 134-143.

[19] Chami, N. \& Zoughaib, A. (2010). Modelling natural convection a pitched thermosyphon system in building roofs and experimental validation using particle image velocimetry. Energy and Buildings, 42(8), 1267-1274. 
[20] Miller, W.A., Wilson, J. \& Karagiozis, A. (2006). The impact of above-sheeting ventilation on the thermal and moisture performance of steep-slope residential roofs and attics. In '15th Symposium on improving buildings systems in hot and humid climates, Orlando, Florida.

[21] Nusser, B. \& Teibinger, M. (2013). Experimental investigations about the air flow in the ventilation layer of low pitched roofs. In '2nd Central European Conference on Building Physics, Vienna, Austria', 827-834.

[22] He, W. Hong, X. Luo, B. et al. (2016). CFD and comparative study on the dual-function solar collection with and without tile-shaped covers in water heating mode. Renewable Energy, 86, 12051214.

[23] Geurts, C. Blackmore, P. (2013). Wind loads on stand-off photovoltaic systems on pitched roofs. Journal of wind engineering and industrial aerodynamics, 123 (SI), 239-249.

[24] Yang, Y. Wang, Q., Xiu, D. et al. (2013). A building integrated solar collector: all -ceramic solar collector. Energy and Buildings, 62, 15-17.

[25] Gan, G. (2009). Numerical determination of adequate air gaps for building integrated photovoltaics. Solar Energy, 83(8), 1253-1273.

[26] Ntinas, G.K., Zhang, G., Fragos, V.P. et al. (2014) Airflow patterns around obstacles with arched and pitched roofs: wind tunnel measurements and direct simulation. European journal of mechanics B-fluids, 43, 216-229.

[27] Letchford, CW., Row, A., Vitale, A. et al. (2000). Mean wind loads on porous canopy roofs. Journal of Wind Engineering and Industrial Aerodynamics, 84(2), 197-213.

[28] Quan, Y., Tamara, Y. \& Matsui, M. (2007). Mean wind pressure coefficients on surfaces of gableroofed low-rise buildings. Advances in Structural Engineering, 10(3), 259-271.

[29] Wang, S., Shen, Z. \& Gu, L. (2012). Numerical simulation of buoyancy-driven turbulent ventilation in attic space under winter conditions. Energy and Buildings, 47, 360-368.

[30] Hagentoft, CE. \& Kalagasidis A. (2014). Moisture safe cold attics - assessment based on risk analyses of performance and cost. In 'Proceedings of the 10th Nordic Symposium on Building Physics', 1366-1373.

[31] Langmans, J., Klein, R., Roels, S. (2013). Hygrothermal risks of using exterior air barrier systems for highly insulated light weight walls: A laboratory investigation. Building and Environment, 56 (10), 192-202.

[32] Wahlgren, P. (2007). Overview and literature survey of natural and forced convection in attic insulation. Journal of Building Physics, 30(4), 351-370.

[33] Desmarais, G., Derome, D., \& Fazio, P. (2000). Mapping of air leakage in exterior wall assemblies. Journal of Building Physics, 24, 132-154. doi:10.1106/BWH8-9D3J-R939-957E [34] Kalamees, T., \& Vinha, J. (2003). Hygrothermal calculations and laboratory tests on timberframed wall structures. Building and Environment, 38(5), 689-697.

[35] Langmans, J., Klein, R., \& Roels, S. (2012). Hygrothermal risks of using exterior air barrier systems for highly insulated light weight walls: a laboratory investigation. Building and Environment, 56(10), 192-202.

[36] Janssens, A., \& Hens, H. (2003). Interstitial condensation due to air Leakage: a sensitivity analysis. Journal of Thermal Envelope and Building Science, 27(1), 15-29.

[37] Klarsfeld, S. \& Combarnous, M. (1980), 'Analyse des transferts thermiques convectifs dans les isolants poreux perméables', Revue generale de thermique 228, 977-983.

[38] Wahlgren, P. (2002). Measurements and simulations of natural and forced convection in loose-fill attic insulation. Journal of Building Physics, 26(1), 93-109.

[39] Wahlgren, P. (2005). Variation in onset of natural convection in loose-fill attic insulation due to geometry and materials. In 7th symposium on Building Physics in the Nordic Countries, Reykjavik. [40] Langlais, C., Arquis, E. and McCaa, D.J. (1990). A Theoretical and Experimental Study of Convective Effects in Loose-Fill Thermal Insulation, Insulation materials: Testing and Applications, ASTM STP 1030, Philadelphia, pp. 290, Ins

[41] Serkitjis, M. and Hagentoft, C.-E. (1998). The Influence of Natural Convection on the Heat Transfer in an Air Filled Porous Medium Bounded by an Air Layer, The Nordic Journal of Building Physics.

[42] Weber, J. E. (1975). The boundary-layer regime for convection in a vertical porous layer. International Journal of Heat and Mass Transfer, 18(4), 569-573.

[43] Janssens, A. (1998). Reliable control of interstitial condensation in lightweight roof systems: calculation and assessment methods. K.U.Leuven, Laboratorium Bouwfysica, Heverlee.

[44] Langmans, J., Nicolai, A., Klein, R., \& Roels, S. (2012). A quasi-steady state implementation of air convection in a transient heat and moisture building component model. Building and Environment, 58. 
[45] Bories, S.A. 1987. Natural convection in porous media. Advances in transport phenomena in porous media (eds. J. Bear and M.Y. Corapcioglu). Martinus Nijhoff, the Netherlands, 77-141.

[46] Nield, D. A.,\& Bejan, A. (1993). Convection in porous media (3rd ed.). Springer-Verslag New York.

[47] Yarbrough, D. W., \& Wudhapitak, S. (1992). Air permeability of loose-fill residential insulations. In 8th international conference on thermal insulation (pp. 8-14). Millbrae, California.

[48] Lorentzen, G. \& Brendeng, E. (1959), On the influence of free convection in insulated vertical walls, in '10th International congress of refrigeriation', p. 294.

[49] Bankvall, C. (1972), Natural convective heat transfer in insulated structures, PhD thesis, Division of building technology, Lund institute of technology, Sweden, Lund, Sweden.

[50] Silberstein, A., Langlais, C. \& Arquis, E. (1990), 'Natural convection in light fibrous insulating materials with permeable interfaces: onset criteria and its effect on the thermal performances of the product', Journal of Thermal Insulation and Building Envelopes 14(1), 22-42.

[51] Klarsfeld, S. \& Combarnous, M. (1980), 'Analyse des transferts thermiques convectifs dans les isolants poreux perméables', Revue generale de thermique 228, 977-983.

[52] Lecompte, J. (1989), The influence of natural convection on the thermal quality of insulated cavity walls constructions (in Dutch), PhD thesis, Departement of Civil Engineering, KU Leuven, Belgium.

[53] Dyrbøl, S., Svendsen, S. \& Elmroth, A. (2002), 'Experimental Investigation of the Effect of Natural Convection on Heat Transfer in Mineral Wool', Journal of Building Physics 26(2), 153-164.

[54] Houvenaghel G. Horta A., Hens H. (2004). The Impact of Airflow on the Hygrothermal Behavior of Highly Insulated Pitched Roof Systems, Proceedings, International Conference for Performance of Exterior Envelopes of Whole Buildings IX, December 5-10, 2004, U.S. Department of Energy, Oak Ridge National Laboratory

[55] ISO 10456:2007. Building materials and products -- Hygrothermal properties -- Tabulated design values and procedures for determining declared and design thermal values

[56] Bjerkevoll, G. O. (1994), Hot box measurements on structures with thick insulation layer, Master thesis, Department of Civil and Transport Engineering, Norwegian University of Science and Technology, Norway.

[57] Johannessen, E. (1995), Hot box measurements on Structures with thick insulation layer. Examination work (In Norwegain), PhD thesis, NTNU.

[58] Janssen, H. (1997), Thermal performance of highly insulated wood frame walls, Master thesis, Norwegian University of Science and Technology, Norway.

[59] Riesner, K. (2003), Natural convection in exterior walls (in German), Phd thesis, Univeristy of Rockstock, Germany.

[60] Timusk, J., Seskus, A. \& Ary, N. (1991), 'The control of wind cooling of wood frame building enclosures', Journal of buildings Physics 15(1).

[61] Ojanen, T. \& Kohonen, R. (1995), Hygrothermal performance analysis of wind barrier structures, in 'ASHRAE Transactions', Chicago, USA.

[62] Langmans, J., Klein, R., \& Roels, S. (2010). Air Permeability Requirements for Air Barrier Materials in Passive Houses. In International Symposium on Building and Ductwork Air-tightness. Copenhagen, Denmark: Energie + Umwelt Zentrum.

[63] Ogle, R. and O'Conner, J. (1995). Failure of the building envelope: two case studies.

Proceedings of the sixth ASHRAE/DOE/BETEC Conference. ASHRAE Speical publications, Atlanta

GA, 379-390.

[64] Messer HWE. (1996) Air and vapour barrier arrangements for public buildings in the Northwest Territories, Canada. Journal of Thermal Insulation and Building Envelopes, 19, 386-403.

[65] Lecompte, J. (1990). Energy — insulation. Batiment International, Building Research and Practice, 18(6), 349-354.

[66] Di Lenardo (2000), A Method for Evaluating Air Barrier Systems and Materials, Institute for Research in Construction, Construction Technology Update (46)

[67] Holøs, S. B., \& Relander, T.-O. (2010). Airtightness Measurements of Wood Frame Low Energy Row Houses. In BEST conference (pp. 1-11). Portland.

[68] Silberstein, A., \& Hens, H. (1996). Effects of air and moisture flows on the thermal performance of insulations in ventilated roofs and walls. Journal of Thermal Insulation and Building Envelopes, 19(4), 367-385. 